\title{
Slavic research group at the University of Ottawa
}

Abstract: The article describes the creation of a Slavic research group at the University of Ottawa and its activities. The main task of the group when it was created was to unite a number of scholars in order to master and better understand the world of Slavic literature and culture. One of the tasks of the Slavic research group was the study of Russian and Polish languages, which are taught to students of the University of Ottawa. The article describes the composition of the group, its gradually expanding activities, including it's today cooperation with a number of leading scientific organizations of the world, active publishing and search work aimed at clarifying data on Russian and Polish literature, archival research, lectures, conferences, exhibitions and festivals.

Keywords: Slavic research group, Russian culture, Polish culture, University of Ottawa, international cooperation, academic centers, Russian literature

Information about the author: Andrew A. Donskov, DSc in Philology, Professor, Slavic research group at the university of Ottawa, Ottawa, Canada

E-mail: adonskov@uottawa.ca

Received: September 03, 2019

Published: December 10, 2019

For citation: Donskov A. A. Slavic research group at the University of Ottawa. Two centuries of the Russian classics, 2019, vol. 1, № 2, pp. 186-195. (In Russ.) DOI 10.22455/26867494-2019-1-2-186-195 


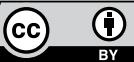

This is an open access article distributed under the Creative

Commons Attribution 4.0

International (CC BY 4.0)

(C) 2019. А. А. Донсков

г. Оттава, Канада

\section{Славянская исследовательская группа в университете г. Оттава}

Аннотация: В статье рассказывается о возникновении Славянской исследовательской группы в университете г. Оттавы и ее деятельности. Основной задачей создания группы было объединение ряда ученых с целью освоения и лучшего понимания мира славянской литературы и культуры, изучения русского и польского языков, которые преподаются студентам университета Оттавы. В статье рассказывается о составе группы, о ее постепенно расширяющейся деятельности. Сегодня Славянская исследовательская группа сотрудничает с рядом ведущих научных организаций мира, ведет активную издательскую и поисковую работу, направленную на уточнение данных о русской и польской литературе, архивные разыскания, проводит лекции, конференции, выставки и фестивали.

Ключевые слова: Славянская исследовательская группа, русская культура, польская культура, университет г. Оттавы, международное сотрудничество, академические центры, русская литература

Информация об авторе: Донсков Андрей Александрович, доктор филологических наук (PhD), профессор, Славянская исследовательская группа при университете Оттавы, г. Оттава, Канада

E-mail: adonskov@uottawa.ca

Дата поступления статьи в редакцию: 03.09 .2008

Дата публикации статьи: 10.12.2019

Для иитирования: Донсков А. А. Славянская исследовательская группа в университете г. Оттава // Два века русской классики. 2019. Т. 1. № 2. С. 186-195. DOI 10.22455/2686-7494-2019-1-2-186-195 
The Slavic Research Group (SRG) at the University of Ottawa was created in 1998 as an interdisciplinary centre for research and publication on Slavic themes. It has brought together a number of scholars from diverse disciplines (notably language, linguistics, history and literature, as well as Canadian studies), from diverse branches of Slavdom (especially Russian, Polish and Serbian), and from diverse geographical locations (Ottawa, Toronto, Victoria, Montréal, Lublin, St-Petersburg, Moscow, Yasnaya Polyana) - all to contribute to a better world understanding of Slavic literature and culture. To date, our principal focus has been in the areas of Russian and Polish - the two major Slavic disciplines offered by the Department of Modern Languages\& Literatures at the University of Ottawa - from a Canadian perspective.

The SRG's mandate is to complement and enhance the work of individual departments at the University of Ottawa in undertaking and publishing research on Slavic cultural and literary themes, organising and publishing the proceedings of academic symposia, sponsoring lectures and other cultural events for both academic and local communities, initiating and renewing international contacts with like-minded institutions abroad, and translating documents between Slavic languages and Canada's official languages. Our first twenty years have seen activity in nearly all these areas.

Our Slavic Research Group, whose activities are overseen by the Associate Dean of the Faculty of Arts, comprises faculty members from various departments at the University of Ottawa, as well as external scholars and researchers from other universities and institutions both in Canada and abroad (a list of current members is appended below). Among our distinguished honorary members from Russia have been Lidija Gromova, Galina Galagan, Marina Shcherbakova, Galina Alekseeva and Ljudmila Gladkova. The current SRG Director is Dr Richard Sokoloski, Professor of Polish at the University of Ottawa (see appendix below for a complete list of current members).

Since its inception, a major focus for the SRG has been cultivating ties with prominent academic institutions in the Slavic-speaking world (specifi- 
cally in Poland and Russia). In Poland we signed memoranda of agreement with the Polish Academy of Arts \& Sciences, the Catholic University of Lublin and the Jagiellonian University in Kraków. In Russia, we have formal ties with the Russian Academy of Sciences (in particlar, its Institute of World Literature in Moscow and its Institute of Russian Literature ((Pushkinskij Dom) in St-Petersburg), the Tolstoy Museums in Moscow and Yasnaya Polyana, the Moscow State Institute of International Relataions (MGIMO) and the Canada College at the University of St-Petersburg. Within Canada we have co-operated with the Centre for Research on Canadian-Russian Relations (CRCRR, currently based at Georgian Collegee in Barrie, Ont.), headed by J. Larry Black, also the University of Toronto's Centre for Russian and East European Studies (CREES) and the Institute of Canadian Studies (ICS) at the University of Ottawa.

This collaboration has resulted in more than thirty books published to date, which have collectively engendered a significant number of favourable reviews by prominent Slavic scholars (including Hugh McLean, Irina Paperno, Gary Jahn and Donna Orwin). The overall response has more than justified our decision to base the bulk of our publishing output on archival sources, with research and documentation by leading specialists in their fields, enhancing their value to world scholarship.

A few examples: (a) the three volumes in our Polish Translation Series, published jointly with Towarzystwo Naukowe Katolickiego Uniwersytetu Lubielskiego in Lublin; (b) The unity of peoples in Leo Tolstoy's works, co-published by the Russian Academy of Sciences in Moscow and St-Petersburg; (c) other volumes in our Tolstoy Series, published in conjunction with the State L.N. Tolstoy Museum in Moscow.

Notable in this latter category is a two-volume publication comprising some 1,150 pages entitled: L. N. Tolstoj i N. N. Strakhov: polnoe sobranie perepiski / L. N. Tolstoy and N. N. Strakhov: complete correspondence, ed. A. Donskov, making available for the first time in its entirety the full integrated exchange of letters between Leo Tolstoy and his friend and editorial associate Nikolaj Strakhov. It offers its readers a unique insight into the minds of two great $19^{\text {th }}$ century Russian thinkers as they engage in earnest dialogue on a wide spectrum of religious, philosophical, social and literary questions. The letters are complemented by the editor's introductory essay (in English) and extensive annotations (many drawn from archival sources) prepared by two leading Tolstoy scholars in Moscow: the late Dr Lidija Gromova, who 
was Head of Classical Literature at the Russian Academy of Sciences' Institute of World Literature, and Tat'jana Nikiforova of the State L .N. Tolstoy Museum in Moscow.

These volumes are a sine qua non for any future research into either Tolstoy's or Strakhov's views on life and literature (Strakhov was indeed a philosopher in his own right), or into the nature of their unique personal relationship. Tolstoy often consulted with Strakhov in developing his own literary ideas, and let himself be guided by the latter's highly valued input. The concluding pages of Volume II contain a summary chronological listing of all the letters as well as two indexes (one of Tolstoy's works and the other of personal names).

This publication met with a most enthusiastic reception on the part of Tolstoy specialists. Witness, for example, the following excerpts from a roundtable discussion of the Tolstoy-Strakhov correspondence held on 22 February 2006 at the Institute of World Literature of the Russian Academy of Sciences in Moscow, later published in Tolstoy Studies Journal (XVIII, 2006: 89-95) in Donna Orwin's English translation.

From P. V. Palievskij: "For the first time, we have a completely restored picture of Tolstoy's communication with a contemporary with whom he was completely open, with whom he expected to find and found understanding, and with a man who was indisputably distinguished in his own right. <...> Now we have this book. The comprehensive foreword by A. A. Donskov, unfortunately only in English, explains how it came into being and how invaluable material was retrieved from the archives of Kiev, Pushkin House, and other repositories. It also outlines the entire history of the relationship between Strakhov and Tolstoy. Most importantly, the book enables ideas to speak again, ideas without which, it turns out, we cannot manage today. We extend our thanks to the editors, commentators, and publishers who have brought these ideas back into our lives."

From A. V. Gulin (Editor-in-Chief, Polnoe sobranie sochinenij L. N. Tolstogo): "The publication of the correspondence between Strakhov and Tolstoy is, without question, an extraordinary event. In its intensiveness, intellectual variety, candor of expression, and finally, its duration in time, this correspondence is an exceptional occurrence in Tolstoy's epistolary legacy. <...> Published for the first time as an integrated whole, the correspondence between Tolstoy and Strakhov appears as a monument, a monolith. And it is an amazing monument, both artistically and historically. We have here the 
history of two Russian fates in a critical epoch of Russian history. Tolstoy's famous letters and Strakhov's widely known letters will naturally now be read anew, in the general context of the bilateral correspondence. We are now able to penetrate into its rich, private subject matter and grasp it in one view, to understand how such personages relate to one another, to see them during their development over many years. Everything in this correspondence is fascinating...”

From G. Ja. Galagan (Pushkin House, Russian Academy of Sciences): "The Canadian publication has already played two important roles. First, it clarifies issues in the relationship between Strakhov and Dostoevsky, including biographical details and the circumstances of the final stage of Strakhov's work on the biography of Dostoevsky and his unexpected outburst of hatred. Second, it helps reveal Strakhov's duality as the dominant feature of his emotional life. These new materials helped V. A. Tunimanov show previously unseen but now self-evident material."

Two years later, under "News of the profession" in Vol. XX of the Tolstoy Studies Journal (2008: 112-113) Prof. Donna Orwin of the University of Toronto wrote that the Slavic Research Group's "achievements in the area of Tolstoy studies are remarkable". She continued: "After the fall of the Soviet regime, founder and director Professor Andrew Donskov saw an opportunity to work with Russian colleagues. His chief Russian collaborator, L. D. Gromova-Opul'skaia, at the Institute of World Literature at the Academy of Sciences in Moscow - among her other accomplishments, the world's foremost Tolstoy textologist - agreed, and the two began a collaboration truly in the spirit of Tolstoy an universal brotherhood. Over a period of fifteen years, until Gromova-Opul'kaia's untimely death in 2003, they headed a team of Russian scholars who prepared one volume after another of unpublished Tolstoy materials. These were almost all published through the SRG (jointly with either the Russian Academy of Sciences or the Tolstoy Museum in Moscow), some of them with parallel English translations by John Woodsworth and critical introductions in English by Professor Donskov - and all this apart from Donskov's own monographs on Tolstoy. <...> Every one of the Group's publications is valuable, all are prepared with high standards of scholarship, and not one would exist without the vision and hard work of Professor Donskov and his team."

To mark the occasion of the fifteenth anniversary of the Slavic Research Group (2013), the Tolstoy Studies Journal's Volume XXIV (2012, pp. 122- 
130) devoted a 9-page review to SRG activities and publications, saying its "achievements are truly remarkable, and its contribution to Tolstoy studies, to the Slavic field, and, what is more, to literary studies generally, is enormous". Moreover, this review essay was penned by two world-renowned Slavic scholars: Irina Paperno and Professor Emeritus Hugh McLean. Here are a few brief excerpts: "In fifteen years, a small group of dedicated scholars, headed by Professor Andrew Donskov of the University of Ottawa (the Group's founder and Director), has published a large number of carefully selected and meticulously prepared documents from the vast heritage of Lev Tolstoy, his family, and his circle. <...> It would not be possible to speak of all of these editions, each outstanding in judicious choice of the material, meticulous preparation, and incisive, but unintrusive, commentary. Some, however, clearly stand out.

Especially noteworthy is the monumental edition of Tolstoy's complete correspondence with Nikolai Strakhov, one of the most important documents of Tolstoy's life and thought. In the words of Andrew Donskov, 'the germ of almost all the moral/religious principles [Tolstoy] expounded in the last three decades of his life can be found in his pre-1880 letters to Strakhov.'

It was hard for us to imagine that, with all that has been published over the years by generations of scholars and faithful followers, new material could be uncovered. But we were proven wrong. <...> Many of the Group's editions are a product of joint efforts by the [University] of Ottawa and the Tolstoy Museum in Moscow, as well as the Institute of Russian Literature (Russian Academy of Sciences, St. Petersburg) and the Institute of World Literature (Russian Academy of Sciences, Moscow). Such collaboration offers a remarkable example of what can be achieved in an equal partnership with Russian academic institutions. These editions manifest a degree of friendly cooperation between Russian and Canadian scholars that would have been quite impossible in the Soviet times. Many of the Ottawa Group's publications are bilingual. With this, the Canadian scholars have opened still unexplored, or long neglected, sources to a double audience of English- and Russian-speaking Tolstoy lovers, and to others around the word. In this and other senses, these editions are in themselves a form of dialogue that is worthy of the publishing ventures of the Tolstoy circle.

When Donna Orwin wrote about the Ottawa Group's remarkable contributions in the Tolstoy Studies Journal in 2008, on the tenth anniversary of the Group, she described this as cooperation 'truly in the spirit of Tolstoyan 
universal brotherhood.'Such moments of 'brotherhood' are rare even in the academic community, and it is on this account, too, that these joint publications have won the admiration and gratitude of scholars around the world."

It is not an exaggeration to say that our other joint publications have received, collectively, dozens of equally favourable reviews, and won international acclaim and awards.

For example, Sergej Tolstoy and the Doukhobors: a journey to Canada was published in collaboration with the L. N. Tolstoy Museum in Moscow; the Museum's own Tat'jana Nikiforova was not only the chief compiler but also contributed one of the introductory essays; it garnered laudatory reviews in a number of prominent journals, including the Russian Language Journal, The Slavonic \& East Europen Review, the Slavic \& East European Journal and Revue des Etudes slaves. It was later re-issued with my introduction in a Russian translation by Kuchkovo Pole Publishers in Russia.

L.N. Tolstoy i F. A. Zheltov: Perepiska was also published jointly with the Tolstoy Museum; it was reviewed in Russkaja literatura, Germano-Slavica, Slavonica and The Social Science Journal, among others. It was later republished by Ethel Dunn at the Highgate Road Social Science Research Station in California (in conjunction with the SRG) in an English translation by John Woodsworth (A Molokan's search for truth: the correspondence of Leo Tolstoy and Fedor Zheltov) and reviewed additionally in the Tolstoy Studies Journal,Canadian Slavonic Papers and Modern Language Review.

Another joint publication, this time with IMLI, was Marina Shcherbakova's volume Ivan Aksakov - Nikolaj Strakhov: Correspondence, which was also highly acclaimed in the Western press.

In more recent years the Slavic Research Group has entered into co-operative ventures with the University of Ottawa Press. Three of its members played a distinctive role in the publication of two landmark volumes regarding Sofia Andreevna Tolstaya (Leo Tolstoy's wife of 47 years) - Andrew Donskov as editor with John Woodsworth and Arkadi Klioutchanski as co-translators. In 2010 the Press released Tolstaya's extensive autobiographical memoir My life, a mammoth 1240-page volume including a 64-page section of colour illustrations, a selected genealogy, a critical editorial essay, a bilingual poetry appendix, a chapter outline, a footnote index and an index of Tolstoy titles. The second book comprised a selection of some 250 letters (out of approximately 1,500 the couple exchanged over their lifetime) and included - in addition to most of the features mentioned for the first 
book - a Foreword by Vladimir Il'ich Tolstoy, a translators' note, a selected chronology and a list of periodical titles. Contributing to this second major volume was a third co-translator, Ljudmila Gladkova, Senior Researcher and Deputy Director of the Moscow Tolstoy Museum, with her comprehensive knowledge of both Tolstoy and his family, especially Sofia Andreevna.

Over the years we at the Slavic Research Group have been most grateful for the collaboration with our colleagues in Slavic-speaking countries. In addition to those already mentioned, we may cite in particular (in alphabetical order): Sergej Arkhangelov, Valentina Bastrykina, Tat'jana Gorjaeva, Zinaida Ivanova, Natal'ja Kalinina, Tat'jana Komarova, Feliks Kuznetsov, Vadim Polonskij, Vitalij Remizov.

Two of our Russian contributors have been accorded special recognition: The late Dr Lidija Gromova-Opul'skaja received a citation engraved on a plaque, while Dr Marina Shcherbakova was awarded a medal struck on the occasion of the 150th anniversary of the University of Ottawa.

The SRG also collaborated with the CRCRR (originally based at Carleton University in Ottawa) in producing the Canada/Russia Series, under the general editorship of J. Larry Black and Andrew Donskov. The first volume in this series was Russian roots \& Canadian wings: Russian archival documents on the Doukhobor emigration to Canada - compiled, translated and annotated by the SRG's John Woodsworth, who has done a number of translations for SRG publications. The seventh volume in the series was a monograph by Andrew Donskov: Leo Tolstoy and the Canadian Doukhobors: an historic relationship - soon to be republished in a new, enlarged edition by the University of Ottawa Press.

In addition to actual research and publication, our activities also include hosting conferences, lectures, cultural events and exhibits, film festivals, etc. - many of them in co-operation with the embassies of Slavic-speaking countries here in our nation's capital, and many open to the public at large. For example, the SRG worked with the Russian Embassy to mount two exhibit of the Russian artist Igor' Soldatenkov. In 2003 the then Yugoslav ambassador Dr Miodrag Perišić gave a talk on "Story-telling and the perception of history", while a month later his wife, Žaneta Djukić-Perišić spoke on the role of Yugoslav novelist Ivo Andrić in bridging the East-West gap in South Slavic literature. A number of addresses on Canada-Russia cultural relations have been given to large audiences under SRG auspices at the University of Ottawa by successive Russian ambassadors, notably Vitalij Churkin, Georgij 
Mamedov and Aleksandr Darchiev. We have also hosted talks and initiatives by Polish ambassadors, namely: Bogdan Grzeloński, Paweł Dobrowolski, Zenon Kosiniak-Kamysz, Piotr Ogrodziński and Andrzej Kurnicki.

One of the SRG's aims has been to highlight cultural associations between Slavic peoples and Canada. A major contribution along this line was the hosting (in October 1999) of a major international conference on The Doukhobor centenary in Canada - an historical retrospective on the religious sect known as the Doukhobors, whose persecution-fleeing emigration to Canada in 1899 was financed by Leo Tolstoy himself. He had discovered in their life-style an embodiment of his own philosophical ideas on finding God in individual hearts instead of church hierarchies and a shared rejection of militarism and conscription. Some thirty thousand descendants of these emigrants (many of whom still maintain a knowledge of Russian) make their home in western Canada today, especially Saskatchewan and British Columbia. Conference speakers came from Russia, Britain, the USA and Canada, including scholars from the Doukhobor community itself. The SRG published the Proceedings the following year in collaboration with the Institute of Canadian Studies at the University of Ottawa.

We are grateful for all the support the SRG has received from the university, diplomatic and public communities, as well as for our collaboration with both individual scholars and academic institutions in Canada and abroad. With this support we are encouraged to continue our global outreach through research, publication and cultural activities in the years to come. 